\section{Effects of Feeding Management on Milk Yield and Composition Traits in Crossbred Jersey Cows}

\author{
Savas Atasever*, Ali Vaiz Garipoglu and Huseyin Erdem \\ Department of Animal Science, Faculty of Agriculture, University of Ondokuz \\ Mayis,Samsun, Turkey
}

\begin{abstract}
A B S T R A C T
This aim of this study was to determine the effect of some different feeding and management practices on milk production and traits in Jersey crossbred cows. A total of 78 smallholder dairy farms in the Middle Black Sea region province of Turkey was investigated by raw milk composition (fat (F), protein (P), lactose (L)), density (D), freezing point (FP), somatic cell count (SCC) and daily milk yield (DMY) according to the different feeding applications (grazing (G), silage usage (S), compound feed usage (C), number of milking cow (NMC), calf suckling period (CSP)). Average F $(3.144 \pm 1.931 \%), \mathrm{P}(3.022 \pm 0.448 \%), \mathrm{L}(4.475 \pm 0.669 \%)$ and $\operatorname{logSCC}(5.386 \pm 0.529)$ values were within acceptable ranges. The present investigation revealed that feeding practices had an important role on both milk quality and quantity of Jersey crossbred cows. Therefore, it is suggested that procedures including proper feeding implementations should exactly be managed on the herds.
\end{abstract}
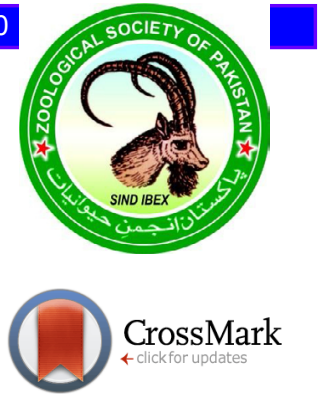

Article Information
Received 29 January 2019
Revised 02 March 2019
Accepted 10 April 2019
Available online 16 April 2020
Authors' Contribution
SA and AVG designed and performed
the experiments, HE ensured analyses
and statistical work, SA, AVG and HE
wrote the manuscript.
Key words
Cow, dairy farm, milk yield, milk
component, management.

\section{INTRODUCTION}

$\mathrm{M}$ $\mathrm{lk}$ yield and composition is of importance for raising economical incomes of dairy farms and also for meeting the nutritional requirements of humans. Milk quality, which is closely related to milk composition, is significant at least as milk yield and for this reason it should be taken into consideration. Milk composition is also important for processing of raw milk to produce milk products such as cheese, butter and yogurt etc (Ahn et al., 2011; Contarini and Povolo, 2013). All these factors put forth the importance of pricing of milk and its products based on their quality.

There are several factors apart from heredity affecting the milk yield and quality. Among these factors are feeding regime, season, diseases, age, lactation stage and milking interval. While some of these factors affect the lactation milk yield, others lead to diurnal effects in milk yield and quality. These factors also can lead to some drawbacks on milk hygiene quality. In this case, total bacteria and somatic cell counts in milk increase and consequently both human health and milk product quality are negatively affected.

The most important factors affecting the milk yield and milk quality are the nutrition level of animals and also ration composition. Under normal nutritional conditions, cows have capacity or ability of producing milk of average

\footnotetext{
* Corresponding author: satasev@omu.edu.tr 0030-9923/2020/0004-1511 \$ 9.00/0

Copyright 2020 Zoological Society of Pakistan
}

quality and yield specific to their races. The feeds with unbalanced composition lead to decrease in milk yield and also, some changes in fat, protein and dry matter contents of milk. Consequently, technological traits and quality of milk is impaired and economical losses can be occurred.

Fat is the mostly affected component of milk by different feeds and feeding practices. The more forage is in ration, the more acetic acid production is in rumen. As acetic acid is the precursor of milk fat, the simplest way of increasing milk fat percentage is to enhance the forage proportion in total ration. But, high amount of forage or low quality forage increase milk fat percentage but decrease milk yield and milk fat yield. Protein is another milk component which is affected by nutritional factors. Use of easily degradable carbohydrates such as starch can lead to increase in milk protein content, but also decreases ruminal acetic acid production and consequently milk fat percentage.

Somatic cell count (SCC), which is a significant milk quality indicator, affects milk composition. The increase in SCC leads to losses in farm economy by decreasing the milk yield (Peeler et al., 2002; Atasever and Erdem, 2009). The increased SSC levels lead to occurrence of undesired taste and aroma in milk and also reduce shelf life of milk and milk products. Furthermore, increased SCC decreases the protein, fat and lactose contents of milk (Rekik et al., 2008).

Freezing point (FP) and density (D) are generally used for determination of adulteration (water addition) or tricks in raw milk (Ayaşan et al., 2011). Both parameters 
are affected by various factors such as nutrition and milking time (Roca-Fernandez, 2014). It was reported that D should be ranged between 1.028 and $1.039 \mathrm{~g} / \mathrm{cm}^{3}$ for Turkey standards (Ayaşan et al., 2011). The minerals found in milk have many vital roles such as bone formation, water balance maintenance, enzyme functions and oxygen transport. Also, organic trace mineral supplementation can improves the production and fertility in lactating dairy cows (Rabiee et al., 2010). While seasonal and regional differences in terms of mineral contents were found significant by some authors (Lindmark-Mansson et al., 2003), feeding of mineral complex to milking cows decreased SCC, increased milk production and improved integrity of hoof tissue (Ramos et al., 2012).

\section{MATERIALS AND METHODS}

The study was carried out at seventy eight smallscale dairy farms in Samsun province, which is located in the Black Sea region of Turkey. The farms had Jersey crossbred cows which were milked two times a day. To evaluate raw milk composition and SCC, $30 \mathrm{ml}$ bulk milk samples were aseptically collected from each farm after morning milking and laboratory analyses were performed in the same day. Contents of fat $(\mathrm{F})$, non-fat dry matter $(\mathrm{NFDM})$, protein $(\mathrm{P})$, lactose $(\mathrm{L})$ and mineral $(\mathrm{M})$, and values for density (D) and freezing point (FP) were analyzed by an automatic milk analyzer (Funke Gerber, Germany). SCC analyses were made with DeLaval cell counter DCC (DeLaval, Sweden). To ensure homogeneity of variance, all SCC values were transformed into log scale $(\log 10)$ for statistical work.

Information related to feeding practices [grazing (G), silage usage (S), compound feed usage (C) daily feed intake (DFI)], milking practices [number of milking cow (NMC), calf suckling period (CSP) and daily milk yield (DMY)] were collected by questionnaires. To evaluate parameters by effective feeding factors; two groups were allocated for each factor and the means were compared on the 0.05 level of probability. The data were tested by independent-simple $t$-test and correlation coefficients among investigated parameters were estimated using Pearson correlation method. All statistical analyses were performed using SPSS 17.0 packet program.

\section{RESULTS}

As seen in Table I, $\mathrm{F}$ increased $(\mathrm{P}<0.05)$ and NFDM, $\mathrm{P}$, $\mathrm{L}$ and $\mathrm{DMY}$ decreased $(\mathrm{P}<0.05)$ in milk samples collected from farms in which cows grazed. The NFDM, P, L, D, FP and SCC were found lower in milk samples obtained from farms in which cows were fed silage $(\mathrm{P}<0.05)$.
Interestingly, all parameters decreased in first group and this difference was significant $(\mathrm{P}<0.05)$ except for $\mathrm{F}, \mathrm{M}$ and DMY, statistically. While no significant effect of FF determined on F, M and SCC, other parameters determined in the second groups were higher than those calculated for the second groups $(\mathrm{P}<0.05)$. From milk components, $F$, NFDM, P, L and D decreased in milk of cows consumed higher feed, however, FP, M, SCC and DMY were not affected by TFC, statistically. Using more staff in feeding (SF) elevated $(\mathrm{P}<0.05)$ NFDM, P, L, D, FP and SCC. In NMC groups, F, FP and SCC were found to be lower, but $\mathrm{D}$ was determined to be higher in the second group. Conspicuously, only $\operatorname{logSCC}$ was significantly $(\mathrm{P}<0.05)$ affected by CSP in the study, and it could be seen from Table I that cows with shorter suckling period had higher $\mathrm{SCC}$ in milk.

In the present study, average $\mathrm{F}(\%), \mathrm{NFDM}(\%), \mathrm{P}$ (\%), L (\%), D, FP, M (\%), logSCC and DMY (kg) were determined to be $3.14 \pm 1.93,8.194 \pm 1.14,3.02 \pm 0.44$, $4.47 \pm 0.66,1.02 \pm 0.005,0.46 \pm 0.04,0.77 \pm 0.07,5.386 \pm 0.529$ and $8.10 \pm 3.13$, respectively.

The correlation coefficients among the investigated parameters are presented in Table II. As seen, F negatively correlated with $\mathrm{D}(\mathrm{P}<0.01)$ whereas positively correlated with FP $(\mathrm{P}<0.01), \mathrm{M}(\mathrm{P}<0.05)$ and $\mathrm{SCC}(\mathrm{P}<0.01)$. Besides, NFDM correlated with P, L, D and FP ( $<<0.01)$. Similarly, correlation coefficients of $\mathrm{P}$ with $\mathrm{L}, \mathrm{D}$ and $\mathrm{FP}$ were highly significant $(\mathrm{P}<0.01)$. While $\mathrm{L}$ correlated with $\mathrm{D}$ and FP $(\mathrm{P}<0.01), \mathrm{D}$ also correlated with FP, significantly $(\mathrm{P}<0.01)$. In addition, significant correlations were determined between FP and $\mathrm{M}(\mathrm{P}<0.01)$ or $\mathrm{SCC}(\mathrm{P}<0.05)$. Intercalarily, DMY only correlated with $\mathrm{M}(\mathrm{P}<0.05)$ and $\operatorname{SCC}(\mathrm{P}<0.01)$.

As seen from Figure 1, highest milk production was obtained in the first SCC group $(\mathrm{P}<0.05)$. After a drastic reduction of DMY by $44.73 \%$, production slightly elevated in the last group ( $\mathrm{SCC}>500 \times 10^{3} \mathrm{cells} / \mathrm{ml}$ ).

\section{DISCUSSION}

Some earlier studies (Neveu et al., 2013; Alstrup et al., 2015; Boerman et al., 2015) revealed that forage caused to increase in milk $\mathrm{F}$ and decrease in milk $P$ percentages. Similar findings were found in our study (Table I). Indeed, the cows those grazed produced milk with rich $\mathrm{F}$ and poor $\mathrm{P}$ content. The higher $\mathrm{F}$ content of milk obtained from forage consuming cows can be due to the fact that forage consumption lead to increase in rumen acetic acid content, which is precursor of milk fat synthesis (Maxin et al., 2011). With regard to obtained $\mathrm{F}$ values, negative effect of forage for NFDM might be assumed to be an expected result. L content decreased due to the 
Table I.- Means ( \pm SD) of milk components, log SCC and DMY according to feeding management factors.

\begin{tabular}{|c|c|c|c|c|c|c|c|c|c|c|c|}
\hline & & $\mathbf{n}$ & F (\%) & NFDM (\%) & $\mathbf{P}(\%)$ & L (\%) & D (gr/cm3) & FP (0C) & M (\%) & $\operatorname{logSCC}$ & DMY (kg) \\
\hline \multirow[t]{2}{*}{ FA } & 1 & 45 & $3.45 \pm 2.45^{\mathrm{a}}$ & $7.85 \pm 1.33^{\mathrm{a}}$ & $2.88 \pm 0.52^{\mathrm{a}}$ & $4.27 \pm 0.77^{\mathrm{a}}$ & $1.02 \pm 0.00^{\mathrm{ab}}$ & $0.46 \pm 0.04$ & $0.76 \pm 0.07$ & $5.42 \pm 0.59$ & $7.80 \pm 2.32^{\mathrm{a}}$ \\
\hline & 2 & 33 & $2.72 \pm 0.59^{b}$ & $8.65 \pm 0.58^{\mathrm{b}}$ & $3.20 \pm 0.22^{\mathrm{b}}$ & $4.75 \pm 0.33^{\mathrm{b}}$ & $1.03 \pm 0.00^{\mathrm{ab}}$ & $0.47 \pm 0.03$ & $0.77 \pm 0.08$ & $5.33 \pm 0.41$ & $8.51 \pm 3.99^{b}$ \\
\hline \multirow[t]{2}{*}{$\mathbf{S}$} & 1 & 17 & $2.45 \pm 1.34$ & $7.99 \pm 1.98^{\mathrm{a}}$ & $2.96 \pm 0.75^{\mathrm{a}}$ & $4.37 \pm 1.12^{\mathrm{a}}$ & $1.02 \pm 0.00^{\mathrm{a}}$ & $0.44 \pm 0.06^{\mathrm{a}}$ & $0.71 \pm 0.07$ & $5.08 \pm 0.66^{\mathrm{a}}$ & $7.26 \pm 2.36$ \\
\hline & 2 & 61 & $3.33 \pm 2.03$ & $8.25 \pm 0.79^{\mathrm{b}}$ & $3.04 \pm 0.32^{\mathrm{b}}$ & $4.50 \pm 0.48^{\mathrm{b}}$ & $1.02 \pm 0.00^{\mathrm{b}}$ & $0.47 \pm 0.03^{\mathrm{b}}$ & $0.78 \pm 0.07$ & $5.47 \pm 0.45^{\mathrm{b}}$ & $8.33 \pm 3.29$ \\
\hline \multirow[t]{2}{*}{ FF } & 1 & 22 & $3.08 \pm 0.86$ & $9.07 \pm 0.67^{\mathrm{a}}$ & $3.36 \pm 0.26^{\mathrm{a}}$ & $4.98 \pm 0.38^{\mathrm{a}}$ & $1.03 \pm 0.00^{\mathrm{a}}$ & $0.49 \pm 0.02^{\mathrm{a}}$ & $0.78 \pm 0.08$ & $5.41 \pm 0.45$ & $6.50 \pm 2.21^{\mathrm{a}}$ \\
\hline & 2 & 56 & $3.16 \pm 2.22$ & $7.84 \pm 1.11^{\mathrm{b}}$ & $2.88 \pm 0.43^{\mathrm{b}}$ & $4.27 \pm 0.65^{\mathrm{b}}$ & $1.02 \pm 0.00^{\mathrm{b}}$ & $0.45 \pm 0.04^{\mathrm{b}}$ & $0.76 \pm 0.07$ & $5.37 \pm 0.56$ & $8.73 \pm 3.23^{\mathrm{b}}$ \\
\hline \multirow[t]{2}{*}{ TFC (kg) } & 1 & 45 & $3.11 \pm 0.83^{\mathrm{a}}$ & $8.51 \pm 0.80^{\mathrm{a}}$ & $3.14 \pm 0.31^{\mathrm{a}}$ & $4.66 \pm 0.46^{\mathrm{a}}$ & $1.03 \pm 0.00^{\mathrm{a}}$ & $0.47 \pm 0.03$ & $0.76 \pm 0.08$ & $5.59 \pm 0.39$ & $7.00 \pm 2.43$ \\
\hline & 2 & 33 & $3.18 \pm 2.83^{\mathrm{b}}$ & $7.75 \pm 1.39^{\mathrm{b}}$ & $2.84 \pm 0.54^{\mathrm{b}}$ & $4.21 \pm 0.81^{\mathrm{b}}$ & $1.02 \pm 0.00^{\mathrm{b}}$ & $0.45 \pm 0.05$ & $0.77 \pm 0.07$ & $5.10 \pm 0.55$ & $9.60 \pm 3.39$ \\
\hline \multirow[t]{2}{*}{ SF } & 1 & 48 & $2.87 \pm 1.89$ & $7.88 \pm 1.19^{\mathrm{a}}$ & $2.90 \pm 0.46^{\mathrm{a}}$ & $4.30 \pm 0.69^{\mathrm{a}}$ & $1.02 \pm 0.00^{\mathrm{a}}$ & $0.45 \pm 0.04^{\mathrm{a}}$ & $0.77 \pm 0.07$ & $5.31 \pm 0.58^{\mathrm{a}}$ & $8.65 \pm 3.43$ \\
\hline & 2 & 30 & $3.58 \pm 1.93$ & $8.69 \pm 0.88^{\mathrm{b}}$ & $3.21 \pm 0.35^{\mathrm{b}}$ & $4.75 \pm 0.53^{b}$ & $1.03 \pm 0.00^{\mathrm{b}}$ & $0.48 \pm 0.03^{\mathrm{b}}$ & $0.76 \pm 0.09$ & $5.49 \pm 0.40^{\mathrm{b}}$ & $7.21 \pm 2.38$ \\
\hline \multirow[t]{2}{*}{ NMC } & 1 & 27 & $3.64 \pm 2.94^{\mathrm{a}}$ & $7.95 \pm 0.97$ & $2.92 \pm 0.40$ & $4.32 \pm 0.60$ & $1.02 \pm 0.00^{\mathrm{a}}$ & $0.47 \pm 0.02^{\mathrm{a}}$ & $0.78 \pm 0.06$ & $5.45 \pm 0.39^{\mathrm{a}}$ & $10.05 \pm 3.50$ \\
\hline & 2 & 51 & $2.87 \pm 1.01^{\mathrm{b}}$ & $8.32 \pm 1.21$ & $3.07 \pm 0.46$ & $4.55 \pm 0.69$ & $1.02 \pm 0.00^{\mathrm{b}}$ & $0.46 \pm 0.05^{\mathrm{b}}$ & $0.76 \pm 0.08$ & $5.34 \pm 0.58^{\mathrm{b}}$ & $7.06 \pm 2.37$ \\
\hline \multirow[t]{2}{*}{$\operatorname{CSP}(d)$} & 1 & 45 & $2.78 \pm 1.86$ & $7.96 \pm 1.13$ & $2.93 \pm 0.43$ & $4.34 \pm 0.65$ & $1.02 \pm 0.00$ & $0.45 \pm 0.04$ & $0.75 \pm 0.08$ & $5.41 \pm 0.59^{\mathrm{a}}$ & $9.22 \pm 3.23$ \\
\hline & 2 & 33 & $3.63 \pm 1.93$ & $8.51 \pm 1.09$ & $3.13 \pm 0.44$ & $4.64 \pm 0.65$ & $1.02 \pm 0.00$ & $0.48 \pm 0.03$ & $0.78 \pm 0.07$ & $5.34 \pm 0.43^{b}$ & $6.57 \pm 2.26$ \\
\hline Total & & 78 & $3.14 \pm 1.93$ & $8.19 \pm 1.14$ & $3.02 \pm 0.44$ & $4.47 \pm 0.66$ & $1.02 \pm 0.00$ & $0.46 \pm 0.04$ & $0.77 \pm 0.07$ & $5.38 \pm 0.52$ & $8.10 \pm 3.13$ \\
\hline
\end{tabular}

Different superscript letters in the same column indicate statistically significant differences $(\mathrm{P}<0.05)$.

$\mathrm{FA}$, forage area $(1: y e s, 2: \mathrm{no}) ; \mathrm{S}$, giving silage $(1: y e s, 2: \mathrm{no}) ; \mathrm{FF}$, giving factory feed $(1: y e s, 2: \mathrm{no})$; TFC, total feed given per milking cow $(1=<7 \mathrm{~kg}, 2=\geq 7 \mathrm{~kg})$ $\mathrm{SF}=$ number of staff in feeding $(1=1$ or $2,2=\geq 3)$, NMC, number of milking cow $(1=1$ or $2,2=\geq 3)$; CSP, calf suckling period $(1=<120 d, 2=\geq 120 d)$ NFDM, non-fat dry matter; FP, freezing point; DMY, daily milk yield (kg)

Table II.- Correlation coefficients among milk components, DMY and SCC.

\begin{tabular}{lllllllll}
\hline & NFDM & Protein & Lactose & Density & FP & Mineral & SCC & DMY \\
\hline Fat & -0.146 & -0.191 & -0.203 & $-0.548^{* *}$ & $0.385^{* *}$ & $0.290^{*}$ & $0.425^{* *}$ & -0.023 \\
NFDM & & $0.998^{* *}$ & $0.998^{* *}$ & $0.906^{* *}$ & $0.727^{* *}$ & 0.148 & 0.215 & -0.131 \\
Protein & & & $1.000^{* *}$ & $0.924^{* *}$ & $0.690^{* *}$ & 0.107 & 0.197 & -0.135 \\
Lactose & & & & $0.928^{* *}$ & $0.685^{* *}$ & 0.107 & 0.193 & -0.136 \\
Density & & & & & $0.452^{* *}$ & 0.005 & -0.002 & -0.091 \\
FP & & & & & $0.707^{* *}$ & $0.271^{*}$ & 0.011 \\
Mineral & & & & & & -0.054 & $0.229^{*}$ \\
SCC & & & & & & & & $-0.406^{* *}$ \\
\hline
\end{tabular}

$* \mathrm{P}<0.05, * * \mathrm{P}<0.01$; NFDM, non-fat dry matter; FP, freezing point; SCC, somatic cell count; DMY, daily milk yield.

forage usage in present study. This finding was supported by some previous studies (Aguerre et al., 2011; Neveu et al., 2013), but not by another study (Machado et al., 2014), which report no difference in milk $\mathrm{L}$ content due to the forage usage. The increase in milk L content due to the use of compound feed in diet can be attributed to synthesis of propionic acid and glucose production in the intermediary metabolism. This formed glucose which then is converted to $\mathrm{L}$ in milk (Machado et al., 2014). Milk $\mathrm{P}$ content followed the same trend as milk L content. Normally, the increase in milk $\mathrm{P}$ content can be attributed to increase in consumption of concentrate feed. In an earlier study
(Tarkowski, 2008) percentage of $\mathrm{P}$ and $\mathrm{F}$ was found to be higher by $4-7 \%$ in group of cows which took factory feed. In addition, some authors (Gonzalez et al., 2015) indicated that rations with low fiber may lead to reduced milk fat content and to avoid fat depression of milking cows, minimum of $25 \%$ dietary neutral detergent fiber (NDF) was suggested. As known, all the dairy feeding strategies are performed by estimating feed intake capacity and performance of the dairy cows (Tarkowski, 2008). That's why, rations by forage and concentrate should be balanced according to milk test results and performances of the cows in each dairy farms. Interestingly, farms without 
any forage area had more DMY in our study. The overall DMY had been calculated to be $8.10 \pm 3.13 \mathrm{~kg}$, and no wide variation among the investigated farms could be regarded as the possible reasons. Also, in spite of no FA allottment in the second group, it might be ensured to the farms by fodder sellers. This subject needs more information using detailed questionnaires with further investigations.

For normal process in rumen fermentation and obtaining more milk production, silage is greatly needed in dairy enterprises (Dewhurst, 2013). However, species of the forage used in silage had a great importance on feed intake and milk production of dairy cows (Steinhamn, 2010). In addition to observed elevation of milk components (NFDM, P, L, D and FP) in milk collected from cows reared in farms where no silage given in feeding applications, a significant increment in log SCC was also determined in the same group in our study (Table I). As a general expression, SCC is a principal marker for detecting raw milk and elevation in this number causes to drop in milk production (Mikone Jonas et al., 2016). The finding here indicates to positive effect of silage for SCC which has been assumed as a reliable criteria for quality of milk.

In farms where factory feed is given to milking cows, NFDM, P, L, D, FP of milk were found to be higher compared to those who did not get factory feeds (Table I). Essentially, this case clearly indicates that FF positively affected five milk components. However, DMY decreased with FF in the farms. In normal, concentrate feedstuffs stimulate cow's milk production. Selected cow breed of this study was not high producer, and also, relatively lower samples had been evaluated in the first FF group. Therefore, these cases might be assumed to be the possible reasons for this unexpected finding for DMY. In other words, because of the fairly low DMY mean for a dairy breed $(8.102 \pm 3.137 \mathrm{~kg})$ and a narrow variation by DMY of the cows in the study might be declared as the feasible reasons of this result.

Elevated F with more TFC indicates that, intensively feeds with high energy content had been presented to the cows in the chosen farms (Table I). Actually, decreased NFDM, L, D and especially $\mathrm{P}$ at the same time support this finding. Thus, the main forages those allotted in lands of the region might be expressed as high $\mathrm{F}$ causing plants. At this point, primarily corn based rations might be given in the investigated herds; however, further works on the effects of different feed sources on milk composition should be conducted to confirm this opinion. In general, more and balanced feed might be expected to result more production. Here, in spite of about $2.6 \mathrm{~kg} / \mathrm{cow}$ more DMY had been taken from second group, no statistical difference was observed between two groups. This finding might be stated to be the narrow variation of DMY values as discussed earlier.

F, NFDM, P, L, D, FP and log SCC increased with farms had more staff in feeding applications (Table 1). Especially, elevated SCC with SF was attractive in this point. As known well, working with more staff in dairy operations is a desirable point for each cattle operations. However, no relationship of staff of the smallholder farms in the same region with milk SCC has been reported (Atasever et al., 2012). In the current investigation, elevated SCC together with more staff indicates that employees might inexactly worked in daily practices such as cleaning, milking or other husbandrial activities those highly affecting SCC in dairy farms. Actually, similar results have also been emphasized in an earlier study that conducted in the region (Atasever et al., 2015).

The present study showed that when NMC increased; F, FP and log SCC dropped but NFDM and D increased (Table I). Approximately $3 \mathrm{~kg}$ more DMY was obtained in farms had lower milking cows but no significant effect of NMC on DMY was determined. As seen that, SCC decreased in relatively crowded herds. This result might be evaluated to be a positive notice for dairy farmers. However, to confirm these connections, further studies containing more farms should be carried out in different dairy breeds.

In this study, only SCC values affected by CSP(Table I). As seen, relatively short CSP positively affected milk SCC in terms of causing a low threshold. At the context, practicing sufficient CSP to the calves could be advised to the herd owner to achieve raw milk with lower SCC from their cows.

Estimated associations of parameters with each other could be seen an expected finding (Table II). Especially, determined moderate or high correlations of SCC with F and FP showed that FP or F could be used as the reliable reflectors to decide quality degree of raw milk similar to SCC. Besides, elevated M and decreased SCC levels might be seen as the important markers to produce more DMY from milking cows.

A dramatic change of DMY with elevated SCC is seen in Figure 1. As seen, cows with lowest SCC had $4.42 \mathrm{~kg}$ and $2.62 \mathrm{~kg}$ more DMY per milking cow when compared to second and third groups, respectively. However, in SCC examination, more than $2 / 3$ of the total milk samples had lower than $500 \times 10^{3}$ cells $/ \mathrm{ml}$ which is the limit for human consumption of raw milk by Turkish Food Codex. This result may be evaluated as a favorable case in the present investigation. It can be noticed that, to obtain more quality milk from herds, taking some limitations especially on hygiene during 
the milking processes or keeping cows more wealthy conditions should be regarded as the major steps.

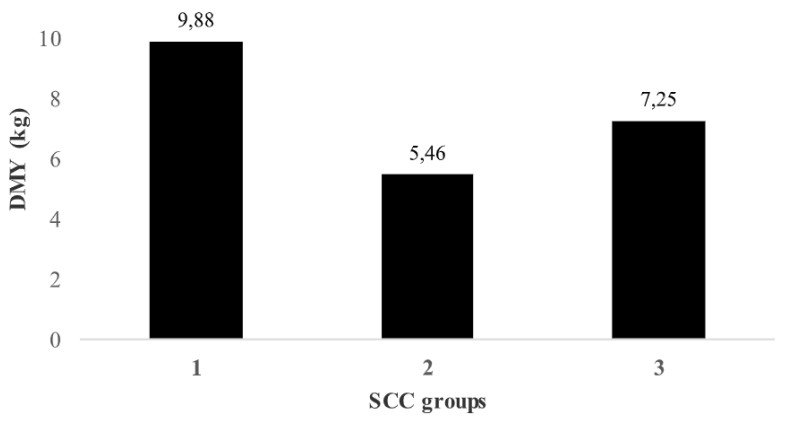

Fig. 1. Change of milk production (DMY) by SCC groups $\left(1=\mathrm{SCC}<200 \times \mathrm{x} 10^{3}\right.$ cells $/ \mathrm{ml} ; 2=\mathrm{SCC}$ between $200 \times 10^{3}$ and $500 \times \times 10^{3}$ cells $/ \mathrm{ml} ; 3=\mathrm{SCC} \geq 500 \times 10^{3}$ cells $/ \mathrm{ml}$ ).

\section{CONCLUSION}

The research revealed that feeding applications have important role on more quality and quantity milk from crossbred Jersey cows. In this point, applying proper feeding management program and monitoring milk parameters can primarily be suggested to farm owners. Besides, further researches focusing each management factor should also be conducted using more dairy enterprises.

\section{Statement of conflict of interest}

The authors have no conflict of interest to declare.

\section{REFERENCES}

Ahn, Y.J., Ganesan, P. and Kwak, H.S., 2011. Composition, Structure, and Bioactive Components in Milk Fat Globule Membrane. Korean J. Fd Sci. Anim. Resour., 31: 1-8. https://doi.org/10.5851/ kosfa.2011.31.1.001

Aguerre, M.J., Wattiaux, M.A., Powell, J.M., Broderick, G.A. and Arndt, C., 2011. Effect of forage-toconcentrate ratio in dairy cow diets on emission of methane, carbon dioxide and ammonia, lactation performance and manure excretion, J. Dairy Sci., 94: 3081-3093. https://doi.org/10.3168/jds.20104011

Alstrup, L., Söegaard, K. and Wesibierg, M.R., 2015. Effects of maturity and harvest season of grassclover silage and of forage-to-concentrate ratio on milk production of dairy cows. J. Dairy Sci., 99: 328-340. https://doi.org/10.3168/jds.2015-9802

Atasever, S. and Erdem, H., 2009. Estimation of milk yield and financial losses related to somatic cell count in Holstein cows raised in Turkey, J. Anim. Vet. Adv., 8: 1491-1494.

Atasever, S., Erdem, H. and Demiryurek, K., 2012. Association of milking parameters with milk quality of smallholder dairy farms in Samsun region, Turkey. J. environ. Biol., 33: 123-126.

Atasever, S., Erdem, H. and Demiryurek, K., 2015. Effects of some farm practices on milk production in dairy farms of Samsun province of Turkey. $2^{\text {nd }}$ Int. Conf. Sustain. Agric. Envir. (2 ${ }^{\text {nd }}$ ICSAE), September 30- October 3, Konya, Turkey.

Ayaşan, T., Hızlı, H., Yazgan, E., Kara, U. and Gök, K., 2011. The Effect of Somatic Cell Count on Milk Urea Nitrogen and Milk Composition. Kafkas Univ. Vet. Fac. J., 17: 659-662.

Boerman, J.P., Potts, S.B., VandeHaar, M.J, and Lock, A.L., 2015. Effects of partly replacing dietary starch with fiber and fat on milk production and energy partitioning. J. Dairy Sci., 98: 7264-76. https://doi.org/10.3168/jds.2015-9467

Contarini, G. and Povolo, M., 2013. Phospholipids in milk fat: Composition, biological and technological significance, and analytical strategies. Int. J. mol. Sci., 14: 2808-2831. https://doi.org/10.3390/ ijms 14022808

Cragle, R.G., Murphy, M.R., Williams, S.W. and Clark, J.H., 1986. Effects of altering milk production and composition by feeding on multiple component milk pricing system. J. Dairy Sci., 69: 282. https:// doi.org/10.3168/jds.S0022-0302(86)80399-X

Demott, B.J., Hinton S.A., Swanson, E.W. and Miles, T.J., 1968. Influence of added sodium chloride in grain ration on the freezing point of milk. J. Dairy Sci., 51: 1363-1365. https://doi.org/10.3168/jds. S0022-0302(68)87195-4

Dewhurst, R.J., 2013. Milk production from silage: comparison of grass, legume and maize silage and their mixtures. Agric. Fd. Sci., 2, 57-69. https://doi. org/10.23986/afsci.6673

Gonzalez, F.H.D., Olmo, D.M.D., Muino, R., Benedito, J.L., Hernandez, J., Castillo, C. and Pereira, V., 2015. Feed sorting and intake affected by the physical form and composition of the total mixed ration in dairy cows. Rev. Bras. Saúde Prod. Anim., 16: 736-745. https://doi.org/10.1590/S151999402015000300023

Lindmark-Mansson, H., Fonden, R. and Pettersson, E.H., 2003. Composition of Swedish dairy milk. Int. Dairy J., 13: 409-425. https://doi.org/10.1016/ S0958-6946(03)00032-3

Maxin, G., Glasser, F., Hurtaud, C., Peyraud J.L. and Rulquin, H., 2011. Combined effects of trans-10, 
cis-12 conjugated linoleic acid, propionate, and acetate on milk fat yield and composition in dairy cows. J. Dairy Sci., 94: 2051-2059. https://doi. org/10.3168/jds.2010-3844

Mikone-Jonas, E., Atasever, S., Graff, M. and Erdem, H., 2016. Non-genetic factors affecting milk yield, composition and somatic cell count in Hungarian Holstein cows. Kafkas Univ. Vet. Fac. J., 22: 361366.

Machado, S.C., McManus, M.C., Stumpf, M.T. and Fischer, V., 2014. Concentrate: Forage ratio in the diet of dairy cows does not alter milk physical attributes. Trop. Anim. Hlth. Prod., 46: 855-859. https://doi.org/10.1007/s11250-014-0576-7

Neveu, C., Baurhoo, B. and Mustafa, A., 2013. Effect of feeding extruded flaxseed with different forage: concentrate ratios on the performance of dairy cows. J. Dairy Sci., 96: 3886-3894. https://doi. org/10.3168/jds.2012-6189

Peeler, E., Green, M.J., Fitzpatrick, J.L. and Green, L.E., 2002. Study of clinical mastitis in British dairy herds with bulk milk somatic cell counts less than 150000 cells/ml. Vet. Rec., 151: 170-176. https://doi.org/10.1136/vr.151.6.170

Rabiee, A.R., Lean, I.J., Stevenson, M.A. and Socha, M.T., 2010. Effects of feeding organic trace minerals on milk production and reproductive performance in lactating dairy cows: A metaanalysis. J. Dairy Sci., 93: 4239-4251. https://doi. org/10.3168/jds.2010-3058

Ramos, J.M., Sosa, C., Ruprechter, G., Pessina, P. and Carriquiry, M., 2012. Effect of organic trace minerals supplementation during early postpartum on milk composition, and metabolic and hormonal profiles in grazing dairy heifers. Span. J. Agric. Res., 10: 681-689. https://doi.org/10.5424/sjar/2012103441-11

Rekik, B., Ajili, N., Belhani, H., Ben Gara, A. and Rouissi, H., 2008. Effect of somatic cell count on milk and protein yields and female fertility in Tunisian Holstein dairy cows. Livest. Sci., 116: 309317. https://doi.org/10.1016/j.livsci.2007.11.001

Roca-Fernandez, A.I., 2014. Animal factors condition milk performance and quality of grazing dairy cows. Iran. J. appl. Anim. Sci., 4: 1-20.

Steinhamn, H., 2010. Effect of forage legumes on feed intake, milk production and milk quality-a review. Anim. Sci. Pap. Rep., 28: 195-206.

Tarkowski, A., 2008. The yield and chemical composition of milk of cows fed the ration with protein-fibrous-extruderate. J. Cent. Eur. Agric., 9: 645-650 